\title{
ADMINISTRAÇÃO PÚBLICA, JURISDIÇÃO CONSTITUCIONAL E VEDAÇÃO AO NEPOTISMO: A CONSTRUÇÃO NORMATIVA DO STF NA SÚMULA VINCULANTE N. 13 E A SALVAGUARDA DOS PRINCÍPIOS DA MORALIDADE E IMPESSOALIDADE ADMINISTRATIVA
}

\section{Vinícius Filipin*}

\section{RESUMO}

O presente artigo enfrenta, enquanto problema de investigação, a possível construção normativa pelo Supremo Tribunal Federal quando da edição da Súmula Vinculante n. 13, em 2008, que veda, em todos os âmbitos de esferas de poder do país, o nepotismo. O objetivo é analisar se os precedentes tidos como vinculativos guardam relação conteudística com o teor da Súmula Vinculante e, se não, quais os limites e possibilidades da jurisdição constitucional na construção de noções jurídicas vinculativas postas de maneira sumular, principalmente quando sobrelevada pela efetivação dos princípios constitucionais da moralidade e impessoalidade administrativa.

Palavras-chave: Jurisdição Constitucional; Súmula Vinculante; Vedação ao nepotismo; Princípio da moralidade administrativa; Princípio da impessoalidade administrativa.

\section{PUBLIC ADMINISTRATION, CONSTITUTIONAL JURISDICTION AND PROHIBITION TO NEPOTISM: THE NORMATIVE CONSTRUCTION OF THE STF IN THE BINDING PRECEDENT N. 13 AND SAFEGUARDING OF THE PRINCIPLES OF MORALITY AND ADMINISTRATIVE IMPERSONALITY}

\begin{abstract}
The article aims to analyze the possible normative construction by Supreme Court when published the binding precedent $\mathrm{n}$. 13, in 2008, which prohibits, in the different spheres of power, the nepotism. The objective is to analyze if the precedents considered as binding maintain a relation of content with the binding precedent and, if not, what are the limits and possibilities of the constitutional jurisdiction in the construction of binding legal notions, especially when accentuated by the implementation of the constitutional principles of administrative morality and impersonality.
\end{abstract}

Keywords: Constitutional Jurisdiction; Binding Precedent; Prohibition of nepotism; Principle of administrative morality; Principle of administrative impersonality.

\section{INTRODUÇÃO}

A vedação ao nepotismo ocupa posição de centralidade na presente pesquisa, que busca analisar como se deu a construção da Súmula Vinculante n. 13, pelo Supremo Tribunal

\footnotetext{
* Mestrando do Programa de Pós-Graduação Stricto Sensu em Direito da Faculdade de Direito da Fundação Escola Superior do Ministério Público (FMP). Especialista em Direito do Estado pela Universidade Federal do Rio Grande do Sul (UFRGS). Bacharel em Direito pela Faculdade de Direito da Fundação Escola Superior do Ministério Público (FMP). Professor Convidado do Programa de Pós-Graduação em Direito Administrativo e Gestão Pública da Faculdade de Direito de Fundação Escola Superior do Ministério Público (FMP). Advogado. E-mail: vini.filipin@gmail.com.
} 
Federal, em agosto de 2008, estendendo a todas as esferas de Poder, de todos os entes da Federação, que a nomeação de cônjuge, companheiro ou parente em linha reta, colateral ou por afinidade, até o terceiro grau, inclusive, da autoridade nomeante ou de servidor da mesma pessoa jurídica investido em cargo de direção, chefia ou assessoramento, para o exercício de cargo em comissão ou de confiança ou, ainda, de função gratificada, compreendido o ajuste mediante designações recíprocas — o nepotismo cruzado —, viola a Constituição Federal.

Tem-se, porém, que o processo decisório que culminou na formulação da Súmula Vinculante n. 13 possa ter se valido de elementos que exorbitam a normatividade da própria súmula, mormente quando questionada a compatibilidade ou conformidade do seu texto com os próprios precedentes tidos como vinculativos. Nesse sentido, urge perquirir os fundamentos utilizados pelo Supremo Tribunal Federal na construção da noção jurídica acerca da vedação às práticas de nepotismo para, cotejando-os com os elementos que constam de quatro destacados precedentes, concluir se houve, ou não, construção normativa pela Corte Constitucional.

O presente texto está organizado dedutivamente, partindo do geral - explicitação da dedução da vedação ao nepotismo a partir dos princípios constitucionais, bem como o próprio fenômeno da constitucionalização do Direito Administrativo - , para o particular, relatando e analisando a edição da Súmula Vinculante n. 13 a partir dos precedentes vinculativos, chegando, finalmente, na consideração acerca a possível construção normativa pelo Supremo Tribunal Federal, sempre alicerçado no dever de guardião constitucional e, nesse sentido, dos princípios norteadores da atividade administrativa postos no caput do artigo 37. Os fios condutores são os limites e as possibilidades da jurisdição constitucional quando da edição de súmulas, bem como a própria noção de nepotismo enquanto afronta aos princípios constitucionais da moralidade e da impessoalidade administrativa.

\section{A CONSTITUCIONALIZAÇÃO DO DIREITO ADMINISTRATIVO E A VEDAÇÃO AO NEPOTISMO COMO DEDUTÍVEL DOS PRINCÍPIOS DA IMPESSOALIDADE E MORALIDADE}

A constitucionalização do Direito Administrativo, enquanto vertente da constitucionalização do Direito, molda-se, conforme Odete Medauar (2017, p. 193), em evolução às expressões clássicas formuladas pela doutrina administrativista estrangeira. Falase, por exemplo, nas "têtes de chapitre", de Pellegrino Rossi, para quem no Direito 
Constitucional é que se encontram os "títulos dos capítulos" do Direito Administrativo". Também, em Georges Vedel (1954), cuja doutrina aponta o reforço das bases constitucionais do Direito Administrativo, do que Bernard Stirn (2006) denomina de "fontes constitucionais".

Sobreleva compreender o processo de constitucionalização do Direito Administrativo como uma releitura e redefinição dos institutos e conceitos daquilo que Gustavo Binenbojm (2008, p. 60) chama de "velha dogmática da disciplina", o entendendo, pois, sob a égide de um sistema principiológico constitucional, a fim de suscitar novos paradigmas que se caracterizem não somente por apresentarem, em si mesmos, um arcabouço teórico fortificado, mas também, e principalmente, por estarem comprometidos com o sistema democrático, com a eficiência impulsora do desenvolvimento, e com o primado e promoção dos direitos fundamentais.

Reforçam-se, portanto, as bases constitucionais do Direito Administrativo de tal modo a sujeitá-lo, sobremaneira, aos direitos fundamentais definidos e previstos constitucionalmente. Por essa razão, Harmut Meurer (2001, p. 23) entende a constituição como formadora do fundamento e do critério de que se dispõe à ordenação jurídica como um todo, informando também a Administração e, por conseguinte, o Direito Administrativo tido, para Fritz Werner (1959, p. 527), como o "Direito Constitucional concretizado".

Antes, porém, a tradição constitucionalista revela que, ainda no decorrer do século XIX, obstou-se a evolução do próprio Direito Constitucional pelas reiteradas quebras de regimes assistidas na Europa e na América Latina, todas seguidas de novos textos constitucionais. Conforme Patrícia Baptista (2003, p. 36-37), a acentuada instabilidade institucional, somada a certa desatenção com o tema dos direitos fundamentais, acabou por comprometer o progresso de uma ciência jurídica constitucional. Os constitucionalistas, naquele contexto de forte influência da Ciência Política, encontravam-se mais preocupados com a consolidação do Estado de Direito.

Ao mesmo tempo, conclui Baptista (2003, p. 36-37), o Direito Administrativo encontrou, influenciado pelas mesmas circunstâncias políticas, condições favoráveis no sentido de afirmar-se como disciplina jurídica autônoma. Diante de tal quadro, com a "circunstancial superioridade científica do Direito Administrativo no âmbito do Direito Público", para além da sua pretensão de neutralidade diante das vicissitudes políticas, fez com

2 Conceito sobre o qual o argentino Manuel Maria Diez desenvolve a ideia de que o Direito Constitucional é a espinha dorsal do Direito Administrativo. Cf. DIEZ, Manuel Maria. Derecho Administrativo. Tomo I. Buenos Aires: Plus Ultra, 1974, p. 323.

Revista de Direito Administrativo e Gestão Pública | e-ISSN: 2526-0073 | Salvador | v. 4 | n. 1 | p. 37 - 55 | 
que doutrinadores sustentassem a total autonomia da matéria, não apenas para com o Direito Privado, mas também aos demais ramos do Direito Público, dentre os quais o Direito Constitucional.

Odete Medauar (2017, p. 197), ao questionar "em que medida o direito administrativo segue efetivamente o rumo traçado pelo direito constitucional?", remonta a Otto Mayer (1949), quando diz que "o direito constitucional passa, o direito administrativo permanece". Aqui, Medauar conclui que, ao proclamar o adágio, Otto Mayer estaria fazendo alusão aos acontecimentos datados de 1914 a 1917 quando, na Alemanha modificou-se profundamente o regime constitucional, substituindo-se a monarquia pela democracia parlamentar, num dos poucos registros de alterações do Direito Administrativo alemão.

Não obstante, conclui Medauar (2017, p. 198-199) que a justificativa buscada nos aspectos políticos e jurídicos do Direito Administrativo e do Direito Constitucional, que despreza, simultaneamente, os aspectos jurídicos deste e os aspectos políticos daquele, não oferece elementos aptos a justificar a frase de Otto Mayer. Assim, mostra-se difícil dar ao direito que cuida da atividade da Administração Pública um caráter pretensamente não político. Não obstante, de qualquer forma que se venha entender o termo "política", inegável é que em toda a atividade administrativa ela está enquadrada.

Com o declínio do positivismo jurídico e do normativismo, a doutrina constitucionalista buscou condicionar o direito positivo ao direito natural ou aos princípios jurídicos supraconstitucionais. Segundo Almiro do Couto e Silva (1997, p. 43), os valores, neste momento, não seriam encontrados no sistema jurídico mesmo, e sim fora dele ou sobre ele. Esta posição, contudo, não encontrou fundamentação teórica que a mantivesse. Partiu-se, daí, ao entendimento pelo qual os valores estão dentro do próprio ordenamento. Vale dizer, estariam nos princípios contidos, explicita ou implicitamente, na Constituição.

Foi à luz desse pensamento que os princípios constitucionais já então identificados viram-se revigorados e ampliados em seus multifacetados aspectos. Os princípios, assim, conforme Almiro do Couto e Silva (1997, p. 43), adquiriram, no que denomina de direito público moderno, especial vigor, sobremaneira "na configuração da coerência e da consistência do sistema". Assim, "as outras normas são sempre a eles necessariamente reconduzidas e são eles que orientam sua interpretação". A constitucionalização do Direito traduz-se, com efeito, no centralismo da Constituição nos ordenamentos jurídicos. 
Reconhece-se à Constituição, portanto, no modelo de Estado Democrático de Direito, status de norma jurídica, de tal modo que seus valores e princípios irradiam-se ao ordenamento, vinculando todos os poderes. A constitucionalização do direito, na lição de Virgílio Afonso da Silva (2005, p. 38), ocorre exatamente no sentido da "irradiação dos efeitos das normas (ou valores) constitucionais aos outros ramos do direito". Assim, as Constituições modernas transmutam a ordem jurídica, fazendo do Estado, de mero garantidor das liberdades individuais e da propriedade, em verdadeiro guardião da ordem social, ampliando os serviços públicos e o Direito Administrativo.

Nesse sentido, conforme Rui Cirne Lima (2007, p. 73), tem-se a Constituição como fonte mais importante do Direito Administrativo, pois esse interessa "pelas linhas de estrutura que traça aos órgãos políticos e a algumas organizações administrativas". Esta ideia bem representa, portanto, a necessidade da Administração Pública brasileira atentar-se ao texto constitucional, em especial, ao disposto no Capítulo VII, intitulado "Da Administração Pública”, cujo artigo inaugural é o destacado art. 37, pelo qual "a administração pública direta e indireta de qualquer dos Poderes da União, dos Estados, do Distrito Federal e dos Municípios obedecerá aos princípios de legalidade, impessoalidade, moralidade, publicidade e eficiência".

É exatamente do teor do art. 37, caput, da Constituição Federal, que se deduz a proibição à prática do nepotismo nas Administrações Públicas brasileiras e, em especial, a partir dos princípios da moralidade e da impessoalidade, junção pela qual acentua-se a lição de Cirne Lima (2007, p. 25) no sentido de que "administrar não é atividade de quem é o senhor de coisa própria, mas gestor de coisa alheia".

Com efeito, o nepotismo, em si, advém, segundo Sérgio Buarque de Holanda (1979, p. 105-108), da dificuldade que parecem possuir os detentores do poder em separar aquilo que público daquilo que é privado. A própria origem do termo é reveladora. Nepotismo vem do latim nepote, e está adstrito à ideia de descendência e parentesco. Dicionários etimológicos italianos, aliás, indicam que a forma latina nepos vem de natus post, ou seja, nascido depois. Esse termo era utilizado para designar tanto sobrinho quanto neto, sentidos mantidos no italiano atual, no qual a palavra "nipote" representa, exatamente, e ao mesmo tempo, sobrinho e neto.

Nesse contexto, a palavra "nepotismo" surgiu na Itália com o intuito de expressar relações de concessões de privilégios dados pelo Papa a seus familiares, pois, no período 
renascentista, pelo fato desta autoridade eclesiástica e, modo geral, outras autoridades não possuírem filhos, acabavam por proteger seus sobrinhos, nomeando-os para ocupar cargos importantes dentro da Igreja Católica (KOOGAN; HOUAISS, 1998).

Estende-se, assim, o conceito do nepotismo do âmbito da igreja à Administração Pública, local que seu conceito ganha notável relevo. Logo, o nepotismo consiste no favorecimento incontrolado de familiares, parentes e cônjuges no que se refere ao acesso a cargo público, em que elementos como competência, formação e idoneidade não são tidos como necessários.

Não se desconhece que o nepotismo tem origem com a própria organização social da humanidade, e com ela evolui. Em estudos concentrados numa possível história natural do nepotismo, Adam Bellow (2006, p. 78-88) traz importantes conclusões que sugerem que o nepotismo advém da própria seleção natural, em que a "seleção por parentesco representa indubitavelmente o ponto de partida do nepotismo humano". Para ele, o nepotismo é a base primordial da cultura, certo que essa, conforme os antropólogos, "constrói-se a princípio com os laços de cooperação entre parentes próximos". Nesse sentido, a seleção tanto por altruísmo quanto por parentesco biológico é que conduz o nepotismo a uma "miríade de laços de parentesco".

No Brasil, a origem do patronato político relaciona-se, conforme Raymundo Faoro (1979), com a própria colonização de Portugal, classificado como um Estado patrimonialista. Com efeito, qualquer traçado de paralelo histórico brasileiro revela a prevalência da dominação dos espaços públicos pelos interesses privados, do que se concentra, até hoje, a manutenção de práticas nepotistas. Ademais, desde suas origens, Portugal dota-se de características patrimonialistas pelas quais a propriedade do rei, ou seja, suas terras e seus tesouros, confundem-se em seus aspectos público e particular, fruto do que Faoro denomina de "estamento burocrático" enquanto dirigente de uma "comunidade amorfa".

Nesse sentido, prossegue Raymundo Faoro:

[...] o estamento é uma comunidade amorfa, seus membros pensam e agem conscientes de pertencer a um mesmo grupo, a um círculo qualificado para o exercício do poder. Ao contrário de classe, no estamento não vinga a igualdade das pessoas - o estamento é um grupo de membros cuja elevação se calca na desigualdade social (FAORO, 1979, p. 45-46).

Como próprio de uma colônia, as influências de Portugal tornaram o Brasil um país que, muito embora independente, não rompeu com as culturas da metrópole, pelo que, 
conforme Faoro (1979, p. 445), "uma camada dirigente aristocrática na sua função e nas suas origens históricas" concentra-se em sua "perpetuidade hereditária, ao eleger filhos e genros, com o mínimo de concessão ao sangue novo".

Assim, sendo o nepotismo peculiar comportamento "caracterizador do patrimonialismo", acaba por identificar o Estado como um negócio de família, sendo, daí por diante, elemento consequente o privilégio dos interesses familiares em detrimento do público, consagrando, conforme Sérgio Buarque de Holanda (1979, p. 141), a histórica confusão entre o público e o privado. O Estado, portanto, nada mais é do que a "ampliação do círculo familiar e, ainda menos, uma integração de certos agrupamentos, de certas vontades particularistas, de que a família é o melhor exemplo".

Desse apanhado histórico é que se extrai a noção jurídica de nepotismo, tido, para Cármen Lúcia Antunes Rocha (1994, p. 158), como "a conduta havida na Administração do Estado, pela qual agentes públicos, valendo-se dos cargos por ele ocupados, concedem favores e benefícios pessoais a seus parentes e amigos". Tem-se, ainda, o conceito de Paulo Modesto:

[...] [nepotismo é] a conduta de nomear para cargos públicos em comissão ou funções de confiança de livre provimento e livre exoneração, ou para cargos e funções de provimento ou exoneração condicionada, parentes, cônjuges ou companheiros de agentes públicos, enaltecendo critérios de promoção familiar e de afinidade em detrimento a critérios de mérito e capacidade funcional no acesso a cargos públicos (MODESTO, 2013, p. 10-11).

Há de pontuar, no entanto, que o conceito de nepotismo evolui no tempo e no espaço, atingindo, atualmente, noções complementares quanto à delimitação do próprio parentesco, bem como o alcance jurídico de quem seja o agente que torna suspeito seus familiares, e em que medida se excetua sua vedação.

De qualquer sorte, e prescindindo de análises pormenorizadas, porquanto cogente a sistematização — ou, melhor, objetivação da presente pesquisa —, tem-se que a noção jurídica atual acerca do nepotismo no ordenamento jurídico brasileiro é dada pela Súmula Vinculante n. 13, cujo teor assim dispõe:

A nomeação de cônjuge, companheiro ou parente em linha reta, colateral ou por afinidade, até o terceiro grau, inclusive, da autoridade nomeante ou de servidor da mesma pessoa jurídica investido em cargo de direção, chefia ou assessoramento, para o exercício de cargo em comissão ou de confiança ou, ainda, de função gratificada na administração pública direta e indireta em qualquer dos Poderes da União, dos Estados, do Distrito Federal e dos Municípios, compreendido o ajuste mediante designações recíprocas, viola a Constituição Federal.

Revista de Direito Administrativo e Gestão Pública | e-ISSN: 2526-0073 | Salvador | v. 4 | n. 1 | p. 37 - 55 | 
Cumpre, assim, analisar o contexto fático-jurídico em que seu a edição da Súmula Vinculante acima descrita, bem como seus precedentes representativos e seu sentido e alcance, para então compreender se há construção normativa pelo Supremo Tribunal Federal.

\section{A EDIÇÃO DA SÚMULA VINCULANTE N. 13 E A CONSTRUÇÃO NORMATIVA DA VEDAÇÃO DO NEPOTISMO PELO STF}

Inicialmente, há de se compreender o lugar que as Súmulas Vinculantes ocupam na Jurisdição Constitucional. Com efeito, "súmula" vem do latim summula, que representa "sumário" ou "índice”. No sentido jurídico, súmula é enunciado jurisprudencial que dispõe de entendimentos pacificados em determinado tribunal, sendo editado, de modo sequencial, a fim de contribuir para o convencimento (ou vinculação) do juiz nas situações processuais futuras.

Assim, na lição de Alfredo Buzaid:

Uma coisa é a lei; outra, a súmula. A lei emana do Poder Legislativo. A súmula é
uma apreciação do Poder Judiciário, que interpreta a lei em sua aplicação aos casos
concretos. Por isso a súmula pressupõe sempre a existência da lei e a diversidade de
sua exegese. A lei tem caráter obrigatório; a súmula revela-lhe o seu alcance, o
sentido e o significado, quando ao seu respeito se manifestam simultaneamente dois
ou mais entendimentos. Ambas têm caráter geral. Mas o que distingue a lei da
súmula é que esta tem caráter jurisdicional e interpretativo. É jurisdicional, porque
emana do Poder Judiciário; é interpretativo, porque revela o sentido da lei. A súmula
não cria, não inova, não elabora lei; cinge-se a aplicá-la, o que significa que é a
própria voz do legislador. Se não entender assim, se a interpretação refugir ao
sentido real da lei, cabe ao legislador dar-lhe interpretaçãa autêntica. A súmula não
comporta interpretação analógica (BUZAID, 1985, p. 215).

A súmula, portanto, expõe o entendimento do Tribunal editor sobre determinado assunto jurídico, valendo de referencial - não obrigatório, portanto - aos magistrados. As súmulas ostentam a função de traduzir, de modo didático, o entendimento predominante daquele Tribunal, possibilitando aos juristas maior facilidade em suas pesquisas jurisprudenciais, assim como aos próprios julgadores, quem pretensamente estariam dispensados de citar diversos precedentes que amparam as decisões que tomam.

Conforme Maués, a projeção judicial da Constituição consolida-se, no século XX, como destacado mecanismo de defesa do próprio Estado Constitucional. Nesse sentido, dois sistemas estão consagrados, o americano e o europeu. Já no Brasil, prossegue, desenvolve-se um sistema que encontra dificuldades de interconectar os elementos que servem de solução aos problemas surgidos, tomando a justiça constitucional de controvérsias decorrentes da concomitância de um modelo de controle difuso e concentrado. Assim, a fim de dirimir as 
divergências entre as decisões dadas pelo Supremo Tribunal Federal e as prolatadas pelas demais instâncias, é que surgem as denominadas Súmulas Vinculantes - com o escopo, repita-se, de diminuir qualquer "divergência jurisprudencial sobre a interpretação da Constituição".

Nesse sentido, a Emenda Constitucional n. 45 tornou a Súmula Vinculante como ferramenta de diálogo e promoção da celeridade processual, alicerçada num conjunto de critérios que, dispostos no artigo 103-A da Constituição Federal, consubstanciam-se na possibilidade de o Supremo Tribunal Federal, de ofício ou por provocação, mediante decisão de dois terços dos seus membros, e após reiteradas decisões sobre matéria constitucional, aprovar a referida Súmula Vinculante — vinculante, pois, aos demais órgãos do Poder Judiciário e à Administração Pública direta e indireta, nas esferas federal, estadual e municipal.

O termo "vinculante" denota a extensão do efeito a todos (Judiciário e Administração Pública), que restam compelidos a atuarem nos estreitos limites da respectiva súmula. O efeito vinculante, portanto, é entendido por João Paulo Fisher Dias no seguinte sentido:

O efeito vinculante ou força vinculante, no seu sentido mais genérico, lato sensu, traduz-se como: liame, laço que cria um vínculo entre sujeitos - uma obrigação que limita as escolhas do sujeito nas suas relações intersubjetivas, sem solapar deste sujeito à liberdade, proporcionando, ao mesmo tempo, estabilidade e segurança nas relações sociais (DIAS, 2004, p. 13).

Assim, é possível entender que pela Súmula Vinculante n. 13, de acordo com o Supremo Tribunal Federal, todas as autoridades nomeantes dos órgãos do Poder Judiciário e da Administração Pública direta e indireta da União, dos Estados, do Distrito Federal e dos Municípios não poderão nomear cônjuge, companheiro ou parente em linha reta, colateral ou por afinidade, até o terceiro grau, inclusive, para o exercício de cargo em comissão ou de confiança ou, ainda, de função gratificada, nem mesmo cônjuge, companheiro ou parente em linha reta, colateral ou por afinidade, até o terceiro grau, inclusive, de qualquer servidor já nomeado para exercer cargo de direção, chefia ou assessoramento, sob pena de violar a Constituição Federal e, em específico, o art. 37, caput, que disciplina o princípio da moralidade e da impessoalidade como regentes da atuação administrativa.

A Súmula Vinculante n. 13 tem como precedentes representativos pelo menos quatro julgados, tidos como paradigmáticos em suas próprias nuances, os quais serão objetos de análise no presente artigo, a fim de que se depreenda e melhor compreenda o alcance da 
construção normativa, ou não, do Supremo Tribunal Federal em matéria de vedação ao nepotismo. Assim, serão sintetizados os principais argumentos de cada um deles, com o escopo de se observar o principal, ou principais, de cada um deles, compreendendo se as discussões travadas pelos Ministros guardam relação - e, se sim, em que medida - com a fundamentação dada pela Suprema Corte quando da edição da Súmula Vinculante.

O primeiro precedente corresponde à Ação Direta de Inconstitucionalidade n. 15214/RS-, que buscou declarar inconstitucionais artigos da Emenda à Constituição do Estado do Rio Grande do Sul n. 12/95, em especial, o art. $1^{\circ}$, que buscou acrescentar ao art. 20 da Constituição Estadual o $\S 5^{\circ}$, que apresenta a seguinte redação:

\begin{abstract}
$5^{\circ}$ - Os cargos em comissão não podem ser ocupados por cônjuges ou companheiros e parentes, consanguíneos, afins ou por adoção, até o segundo grau:

I - do Governador, do Vice-Governador, do Procurador-Geral, do Estado e dos Secretários de Estado, ou titulares de cargos que lhe sejam equiparados, no âmbito da administração direta do Poder Executivo;

II - dos Desembargadores e Juízes de $2^{\circ}$ grau, no âmbito do Poder Judiciário;

III - dos Deputados Estaduais, no âmbito da Assembleia Legislativa;

IV- dos Procuradores de Justiça, no âmbito da Procuradoria-Geral de Justiça;

V - dos Conselheiros e Auditores Substitutos de Conselheiros, no âmbito do Tribunal de Contas do Estado;

VI - dos Presidentes, Diretores-Gerais ou titulares de cargos equivalentes, e dos Vice-Presidentes ou equivalentes, no âmbito da respectiva autarquia, fundação instituída ou mantida pelo Poder Público, empresa pública ou sociedade de economia mista
\end{abstract}

Ademais, o art. $5^{\circ}$ da referida Emenda estabeleceu que "ficam extintos os provimentos, com a respectiva exoneração, dos cargos em comissão providos em desacordo com as disposições do parágrafo $5^{\circ}$, do art. 20, da Constituição do Estado”. Assim, o Procurador-Geral da República ${ }^{3}$ propôs a referida ADIN, aduzindo ofensa à reserva de iniciativa legislativa em matéria pertinente à economia interna de cada um dos Poderes, bem como a transgressão à competência legislativa derivada, pois a Assembleia Legislativa teria disposto sobre provimento e desprovimento de cargos dos demais poderes do Estado. Ademais, suscitou-se a violação ao art. 37, II, da Constituição Federal, que já define os cargos em comissão, não havendo espaço para interpretações distintas, e, também, ofensa a direito adquirido, pois a referida Emenda possui efeitos retroativos que afetam servidores regularmente investidos em cargos em comissão.

3 Conforme consta do relatório do Ministro Relator Ricardo Lewandowski, a propositura da ação pela Procuradoria-Geral da República deu-se mediante solicitação do então Presidente do Tribunal de Justiça do Estado do Rio Grande do Sul, Desembargador Adroaldo Furtado Fabrício, e do Procurador-Geral de Justiça, à época, Dr. Voltaire de Lima Moraes.

Revista de Direito Administrativo e Gestão Pública | e-ISSN: 2526-0073 | Salvador | v. 4 | n. 1 | p. 37 - 55 | 
O Supremo Tribunal Federal, no entanto, entendeu não haver mácula a qualquer dispositivo constitucional a partir da aludida Emenda, pois, ao contrário, de índole exatamente constitucional, porque confere ao tema "nepotismo" tratamento uniforme nos Poderes legislativo, executivo e judiciário do Rio Grande do Sul, proibindo o exercício do cargo pelos parentes consanguíneos e afins até o segundo grau. Ademais, pelo voto do então relator, Ministro Marco Aurélio, restou consignado, pela primeira vez, que "o povo brasileiro já não tateia, mergulhado nas trevas da ignorância em consequente subserviência em busca da mão ditadora e assistencialista". Nesse sentido, prossegue o voto:

O Estado, no exercício das atividades que lhe são inerentes, não pode ignorar os princípios essenciais, que, derivando da constelação axiológica que confere substrato ético às ações do Poder Público, proclamam que as funções governamentais hão de ser exercidas com estrita observância dos postulados da igualdade, da impessoalidade e da moralidade administrativa [...] [Os princípios] [...] erigidos à condição de valores fundamentais pela Carta Política [...] tais postulados qualificam-se como diretrizes essenciais que dão substância e significado a repulsa que busca prevalecer, no âmbito do aparelho do Estado, o sentido real da ideia republicana, que não tolera práticas e costumes administrativos tendentes a confundir o espaço público com a dimensão pessoal do governante, em claro desvio de caráter ético jurídico.

Argumentou-se, portanto, no sentido da necessidade de uma "reflexão mais profunda sobre o sentido ético que lastreia normas deste quilate", dizendo que vedação ao nepotismo representa verdadeira "homenagem aos princípios da legalidade, da impessoalidade, da moralidade e da isonomia",

O segundo julgado diz do Mandado de Segurança 23.780-5/MA, então impetrado por servidora pública ocupante de cargo de provimento efetivo no Poder Executivo Estadual que, no entanto, estava à disposição do Tribunal Regional do Trabalho da $16^{\mathrm{a}}$ Região, onde foi exonerada do exercício de função gratificada, uma vez que o Tribunal de Contas da União, em averiguação de denúncia recebida, considerou que a sua nomeação havia sido ilegal, pois a mesma possuía vínculo de parentesco (irmã) com o então Vice-Presidente do TRT.

$\mathrm{Na}$ ação, o Supremo Tribunal Federal, ao analisar a matéria, considerou que o ato impugnado não apresentava nenhum vício que o tornasse passível de anulação, pois a nomeação da mesma havia ocorrido após a publicação da Decisão n. 118/1994, que acabou por vedar tal espécie de nomeação na seara da Justiça do Trabalho. Igualmente, salientou-se que a Decisão excepciona a nomeação ou designação de servidor titular de cargo público de provimento efetivo para ocupar cargo comissionado ou exercer função gratificada, no âmbito da Justiça Trabalhista, mas que tal ressalva não restava aplicável a então impetrante, pois 
servidora do Poder Executivo do Estado do Maranhão. Nesse sentido, consignou-se que a proibição não alcança o cargo efetivo de cada tribunal, ou seja, os servidores de carreira, tendo sido ressaltado que a única limitação que seria imposta a estes servidores ocupantes de cargo de provimento efetivo seria no sentido de ocuparem cargo comissionado quando vinculado, de modo direto, ao seu parente, ou seja, quando designado para exercer função de direção, assessoramento ou chefia "no gabinete do próprio parente".

Já a Ação Declaratória de Constitucionalidade n. 12-6/DF, tida como a mais importante no tema do nepotismo, intentou a declaração da constitucionalidade da Resolução n. 7, do Conselho Nacional de Justiça, de 2005, pelo qual ficava vedada a prática do nepotismo no âmbito do Poder Judiciário. A referida ADC foi proposta pela Associação dos Magistrados do Brasil (AMB) sob argumentos no sentido de que o CNJ detém competência institucional para "zelar pela observância do art. 37 da Constituição Federal e apreciar a validade dos atos administrativos praticados pelos órgãos do Poder Judiciário”. Além disso, pontuou-se que a vedação ao nepotismo é "regra constitucional que decorre dos princípios da impessoalidade e da moralidade administrativas", e que a Resolução n. 7 não prejudica o necessário equilíbrio entre os Poderes, "nem vulnera o princípio federativo, dado que também não estabelece vínculo de sujeição entre as pessoas estatais de base geográfica”.

Diante desse cenário, o Supremo Tribunal Federal, quando do pronunciamento acerca da medida cautelar, em 16/02/2006, confirmou o substrato constitucional do conteúdo da Resolução, sendo o CNJ competente para editar atos normativos primários, mormente quando seguem "imediatamente a vontade da própria Constituição, sem outra base de validade que não seja a Constituição mesma”. Assim, a vedação ao nepotismo, pelo CNJ, no âmbito do poder judiciário, decorre dos "próprios conteúdos lógicos dos princípios constitucionais da centrada regência de toda a atividade administrativa do Estado", a saber, os dispostos expressamente no art. 37, caput - impessoalidade, eficiência e moralidade —, assim como princípio da igualdade.

Nos termos do voto do Ministro Relator Ayres Britto, "é dizer: o que já era constitucionalmente proibido permanece com essa tipificação, porém, agora, mais expletivamente positivado". O Supremo Tribunal Federal, então, manteve a Resolução do CNJ n. 7/2005, confirmando-lhe a legitimidade e integral eficácia, preservando, no entender dos seus Ministros, a força normativa da Constituição. 
Por fim, tem-se o Recurso Extraordinário n. 579.951/RN, então interposto em face de acórdão proferido pelo Tribunal de Justiça do Rio Grande do Norte que confirmou a legalidade da nomeação de um irmão de um vereador para ocupar o cargo de Secretário de Saúde do mesmo município, onde também o irmão do vice-prefeito foi nomeado para ocupar o cargo de motorista do Poder Executivo. Conforme o colegiado do TJ/RN, não houve qualquer inconstitucionalidade ou ilegalidade nas nomeações. Nesse sentido, afirmou-se, acórdão recorrido, que a Resolução n. 7/2005 do CNJ não poderia ser interpretada de modo extensivo e, portanto, não seria aplicável ao Poder Executivo e Legislativo. Igualmente, argumentou-se que a proibição do nepotismo exige a edição de lei formal, e que a nomeação de parentes de agentes políticos para exercer cargo em comissão não viola nenhum dispositivo constitucional, pois a Constituição Federal atribui a estes cargos o a livre nomeação e exoneração.

O Supremo Tribunal Federal, assim, decidiu no sentido de que não merecia prosperar o entendimento do acórdão recorrido, pois contrário à força normativa dos princípios expostos no art. 37 da Constituição Federal, porque "a vedação ao nepotismo é regra constitucional que está na zona de certeza dos princípios da moralidade e da impessoalidade”. Ademais, consignou-se que a proibição ao nepotismo não ocorre apenas quando decorrente de lei formal, pois corolário da própria aplicação dos princípios da moralidade, impessoalidade, isonomia e, muitas vezes, da eficiência.

Destacou-se, neste julgado, a existência de um "consenso social acerca da reprovabilidade da prática do nepotismo", carecendo de plausibilidade a "exegese segundo a qual o nepotismo seria permitido simplesmente porque não há lei que o proíba”. Com o exposto, foi declarada a nulidade da nomeação do irmão do Vice-Prefeito como motorista. De outra banda, entendeu-se pela legalidade da nomeação do irmão do vereador para ocupar o cargo de Secretário de Saúde, pois cargo de natureza política, firmando-se importante argumento no sentido de que "o Chefe do Poder Executivo é livre para escolher seus quadros de governo, mas não o é para escolher seus quadros administrativos".

Assim:

A Corte concordou - que os princípios do artigo 37 eram extensíveis a toda a Administração Pública, tive em conta a própria expressão -Administração Públicall, porque esses princípios da legalidade, impessoalidade e moralidade vêm num contexto não de governo, não de poder político, mas de Administração Pública, ou seja, para exercício da atividade administrativa. A Administração Pública, aqui, parece-me, é segmento do governo. O governo é mais do que a Administração Pública, porque incorpora ingrediente político. Então, quando o art. 37 refere-se a cargo em comissão e função de confiança, está tratando de cargos e funções

Revista de Direito Administrativo e Gestão Pública | e-ISSN: 2526-0073 | Salvador | v. 4 | n. 1 | p. 37 - 55 | 
singelamente administrativos, não de cargos políticos. Portanto, os cargos políticos estariam fora do alcance da decisão que tomamos na $\mathrm{ADC}$ n. 12, porque o próprio Capítulo VII é Da Administração Pública enquanto segmento do Poder Executivo. E sabemos que os cargos políticos, como, por exemplo, os de Secretário Municipal, são de agentes do Poder, fazem parte do Poder Executivo. O cargo não é em comissão, no sentido do art. 37. Somente os cargos e funções singelamente administrativos - é como penso - são alcançados pela imperiosidade do artigo 37 , com seus lapidares princípios. Então, essa distinção me parece importante para, no caso, excluir do âmbito da nossa decisão anterior os Secretários Municipais, que correspondem a Secretários de Estado, no âmbito dos Estados, e Ministros de Estado, no âmbito federal.

Uma vez expostos e analisados os precedentes representativos, sobreleva analisá-los com a formulação da Súmula Vinculante n. 13, de tal modo a compreender se houve, ou não, por parte do Supremo Tribunal Federal, construção normativa acerca da vedação às práticas de nepotismo.

Com efeito, vê-se que a ADI n. 1521-4/RS, tida como primeiro precedente da Súmula Vinculante, foi julgada improcedente ancorada no argumento de que a vedação ao nepotismo advém da força normativa dos princípios esculpidos no caput do art. 37 da Constituição Federal, sendo somente esse o argumento que revela similaridade deste precedente com os demais. No entanto, ao questionar-se se a redação da Súmula Vinculante n. 13 guarda relação com a redação da Emenda Constitucional objeto da aludida ADI, e se a redação daquela deu-se nos limites da proibição do nepotismo tal como intentado pela Assembleia Legislativa do Rio Grande do Sul, tem-se negativa a resposta.

É que, como visto, a extensão da proibição dada na Emenda à Constituição do Rio Grande do Sul não é a mesma encontrada na redação da Súmula Vinculante, pois essa muito mais abrangente do que aquela, em especial, no sentido de que a Emenda limita a vedação ao segundo grau de parentesco, ao passo que a Súmula amplia para o terceiro grau, inclusive. Ademais, vê-se que a Emenda delimita a autoridade, ao mesmo tempo em que a Súmula Vinculante adiciona o servidor ocupante de cargo comissionado na proibição. Também no que se refere ao local, a Emenda fala em "mesmo órgão", quando a Súmula Vinculante diz da "mesma pessoa jurídica".

Já em relação ao MS n. 23.780-5/MA, vê-se que o único fundamento é, também, que a proibição de práticas nepotistas decorre dos princípios do art. 37, caput, da Constituição Federal, em especial, o da moralidade. Igualmente, ao questionar-se acerca dos elementos que compõe o aludido julgado e a referência destes com o aludido julgado, tem-se negativa a resposta, pois a noção de nepotismo que está expressa na decisão do Tribunal de Contas da 
União, que fora objeto do Mandado de Segurança, é diferente da que se encontra na redação da Súmula Vinculante n. 13. É que a decisão do TCU estabelece relação vinculativa da prática do ato de nepotismo com a autoridade nomeante, ao mesmo tempo em que a Súmula, para além desta vinculação, a estende para servidor ocupante de cargo em comissão. Também, a decisão do TCU não contempla na vedação os servidores efetivos, o que o faz a Súmula Vinculante, que também, e por fim, veda todo tipo de nepotismo em se tratando de servidor efetivo, enquanto que a decisão do TCU veda apenas quando subordinado diretamente ao parente.

Cotejando os dois julgados acima referidos, é possível estabelecer pelo menos três pontos de convergência. O primeiro toca ao grau de parentesco, em que os mesmos estipulam o segundo grau. O segundo está no sentido de que o Supremo Tribunal Federal não estabeleceu maiores critérios acerca do nepotismo, deixando ao legislador para dispor sobre a matéria. $\mathrm{O}$ terceiro reside no fato de que o nepotismo é vinculado à autoridade que possui competência para nomear. De outra banda, também divergem, pois a ADI contempla, na proibição, os servidores efetivos, enquanto que no MS, não. Ademais, naquele o nepotismo é adstrito ao "mesmo órgão", enquanto nesse diz do "gabinete da autoridade".

O terceiro precedente, a ADC n. 12/6-DF, é, como dito, o que possui maior relevo em se tratando da formulação da Súmula Vinculante n. 13, pois a partir daquele julgamento que o Supremo Tribunal Federal decidiu editá-la. Num primeiro momento, como também ocorre nos demais julgados, vê-se que o repúdio às práticas nepotistas decorre da leitura constitucional, ou seja, dos princípios do art. 37. Outro ponto de convergência é, exatamente, o que identifica sua vedação em se tratando do "mesmo órgão", para além do que estabelece prescindível lei formal que venha a vedar o nepotismo.

No entanto, assim como ocorre em relação dos julgados já tratados, tem-se múltiplas diferenças entre os precedentes no sentido da limitação da própria noção de nepotismo, pois enquanto nas primeiras o nepotismo está vinculado à autoridade, nesta ADC o servidor ocupante de cargo em comissão também é abarcado. Depois, enquanto na ADI há delimitação no órgão em que se encontra lotada a autoridade, no MS e nesta ADC a limitação encontra o requisito da subordinação do familiar àquela autoridade. Assim, analisando os precedentes, vê-se que o Supremo Tribunal Federal, até esse momento último, sequer havia elaborado judicialmente seu entendimento acerca da vedação ao nepotismo, não havendo orientação linear sobre seus elementos. 
O conteúdo da Súmula Vinculante n. 13 também não encontra total consonância com a decisão da ADC e, em especial, com a Resolução do CNJ, porquanto tenha aquela ampliado o próprio alcance do nepotismo, construindo, pois, em ato de inovação normativa, os elementos da vedação. Tais elementos são percebidos na alteração de "mesmo órgão" para "mesma pessoa jurídica", também na alteração da expressão "exercício do cargo" para "nomeação", e quando visto que não há exclusão dos servidores efetivos, tal e qual ocorre na Resolução. Contudo, há de se observar que, muito embora inovador no sentido da ampliação da vedação ao nepotismo, a ADC revela-se precedente da Súmula Vinculante n. 13, pois seu objeto, a Resolução n. 7, do CNJ, serviu de base à sua redação.

Por fim, tocante ao RE n. 579-951-RN, tem-se, novamente, a incidência dos princípios constitucionais, mas nota-se que, de modo inovador, tem-se a distinção entre cargos em comissão e cargos políticos, do que o nepotismo englobaria apenas os familiares nomeados para cargos comissionados, e não para cargos políticos (secretários, ministros, etc.). Já no que se refere à sua relação com os demais julgados, tem-se também a noção de que não é necessária a edição de lei formal para que se tenha por coibida a prática do nepotismo. Por outro lado, diverge da ADC, em que o parentesco é elevado ao terceiro grau, enquanto no RE permanece, como nos demais, no segundo.

\section{CONSIDERAÇÕES FINAIS}

A presente pesquisa buscou averiguar a edição da Súmula Vinculante n. 13, pelo Supremo Tribunal Federal, que veda o nepotismo no âmbito das três esferas, no exato sentido de se entender se a Corte Suprema, quando da construção jurisprudencial e quando da construção sumular, exorbitou da normatividade atribuída às súmulas, em especial, as de efeito vinculante.

Tem-se, à guisa de conclusão, que dos debates travados nos precedentes do Supremo Tribunal Federal apontados não é possível retirar todas as pontualidades que constam da noção de vedação ao nepotismo consignado na Súmula Vinculante n. 13. Vê-se, ademais, da leitura do acórdão que originou a Súmula, que se limitou o STF a debater tão somente no sentido da extensão do parentesco (se de segundo ou terceiro grau), e também o âmbito físico desta vedação.

O Supremo Tribunal Federal, portanto, construiu sua noção de nepotismo, e normatizou sua vedação a partir da Resolução do CNJ, objeto do terceiro precedente 
destacado, acrescentando, conforme o RE analisado, a vedação ao nepotismo cruzado, e excluindo os cargos de natureza política do alcance da proibição. Ainda, nos termos apenas do segundo precedente vinculativo, incluíram-se os servidores efetivos, alterando, contudo, o espaço físico, para alancar a "mesma pessoa jurídica" no lugar de "mesmo órgão", o que revela, a bem da verdade, ser a Súmula Vinculante um emaranhado normativo, com elementos retirados de fontes diversas e, muitas vezes, antagônicas, para além daqueles critérios que não são encontrados nem nos julgados tidos como precedentes, nem no entendimento até então construído pela mais elevada corte do país.

Nesse sentido, questionamentos remanescem no sentido dos limites e extensão da criação normativa no âmbito do processo, culminando, muitas vezes, em súmulas que são vinculantes tão somente em suas denominações. De outra banda, entendendo-se que a produção intelectual se presta, quase sempre, a mais questionar que responder, indaga-se, a partir da análise ora proposta, se os princípios constitucionais possuem, de fato, força normativa, e se existe, no nosso ordenamento, a possibilidade destes princípios estabelecerem expressões deônticas que digam do dever ou da proibição, exigindo, por conseguinte, determinadas condutas.

Assim, tem-se que o sistema jurídico — e, em especial, o brasileiro —, muito embora constitucionalizado materialmente por intermédio de regras, princípios e valores, não conta com a clareza necessária no sentido da imprescindibilidade, ou não, das garantais indisponíveis fundamentadas nas decisões das autoridades. Ainda que se possa atribuir à Súmula Vinculante n. 13 uma aura de texto, não se pode olvidar que, nesse cenário, está a lei suscetível de interpretação (e, aqui, leis já foram criadas no sentido de, inclusive, possibilitar práticas nepotistas), enquanto as súmulas vinculantes, na esteira oposta, seriam a própria interpretação cogente.

Questiona-se, assim, a possibilidade de uma Súmula Vinculante agregar legislativamente uma preliminar e exclusiva resposta emanada pelo Supremo Tribunal Federal, o que, por óbvio, torna ainda mais fantástica a discussão acerca da jurisdição constitucional e sua atuação no sentido de salvaguardar a boa aplicação dos princípios que, por determinação emanada do Poder Constituinte — originário e derivado —, norteiam a atividade da Administração Pública.

\section{REFERÊNCIAS}

Revista de Direito Administrativo e Gestão Pública | e-ISSN: 2526-0073 | Salvador | v. 4 | n. 1 | p. 37 - 55 | 
BAPTISTA, Patrícia. Transformações do Direito Administrativo. Rio de Janeiro: Renovar, 2003.

BELLOW, Adam. Em louvor do nepotismo: uma história natural. 1. ed. São Paulo: A Girafa, 2006.

BINENBOJM, Gustavo. Temas de direito administrativo e constitucional: artigos e pareceres. Rio de Janeiro: Renovar, 2008.

BRASIL, Conselho Nacional de Justiça, Resolução n. 7 de 18.10.2005. Publicada e Disponível em: http://www.cnj.jus.br.

. Supremo Tribunal Federal, MS n. 23.780-5/MA, julgada em 28.9.2005, publicada no DJ de 3.3.06. Ementário n. 2223-1. Disponível em: http://www.stf.jus.br.

Supremo Tribunal Federal. RE n. 579.951/RN, julgado em 20.8.2008, publicado no DJ. n. 202, de 24.10.1008, Ementário n. 2338-10. Disponível em: http://www.stf.jus.br.

Supremo Tribunal Federal. Ação Declaratória de Constitucionalidade. ADc n. 126/DF, julgada em 20.8.2008, publicada no DJ n. 237, de 18.12.2009. Ementário n. 2387-1. Disponível em: http://www.stf.jus.br.

. Supremo Tribunal Federal. Ação Direta de Inconstitucionalidade. ADI n. 15214/RS, julgada em 12.3.97, publicada no DJ de 17.03.2000. Ementário nº 1983-1. Disponível em: http://www.stf.jus.br

. Supremo Tribunal Federal. MC - ADc n. 12-6/DF, julgada em 16.2.2006, publicada no DJ de 01.9.2006. Ementário n. 2245-1. Disponível em: http://www.stf.jus.br. Supremo Tribunal Federal. Súmula Vinculante n. 13 de 21.8.2008, DJe n. 162 de 29.8.2008 e Diário Oficial da União, Brasília, DF 29.8.2008.

. Tribunal de Contas da União, Relator Min. Augusto Nardes, Acórdão n. 38/2007, de 31.1.2007, aprovado em 1.2.2007 e publicado no D.O.U de 2.2.2007. Processo: 004.966/2003-4.Disponível em: http://portal2.tcu.gov.br Acesso em: 25.03.2013. COUTO E SILVA, Almiro do. Os indivíduos e o Estado na realização das tarefas públicas. In: BANDEIRA DE MELLO, Celso Antonio (Org.). Direito Administrativo e Constitucional: estudos em homenagem a Geraldo Ataliba. São Paulo: Malheiros, 1997.

DIAS, João Luís Fischer $O$ efeito vinculante: dos precedentes jurisprudenciais: das súmulas dos tribunais. 1. ed. São Paulo: Thomson, 2004.

DIEZ, Manuel Maria. Derecho Administrativo. Tomo I. Buenos Aires: Plus Ultra, 1974. 
FAORO, Raymundo. Os Donos do Poder: Formação do Patronato Político Brasileiro. 5. ed.

Ed. Globo: Porto Alegre, 1979.

HOLANDA, Sergio Buarque de. Raízes do Brasil. 13.ed. Rio de Janeiro: J. Olympio, 1979.

KOOGAN, André; HOUAISS, Antonio. (Ed.). Enciclopédia e dicionário digital 98. São

Paulo: Delta, 1998.

LIMA, Ruy Cirne. Princípios de Direito Administrativo. 7. ed. São Paulo: Malheiros, 2007.

MAURER, Hartmut. Elementos de direito administrativo alemão. Tradução de Luís Afonso

Heck. Porto Alegre: Sérgio Antonio Fabris Editor, 2001.

MAYER, Otto. Derecho administrativo alemán. Tomo I. Buenos Aires: Ed. Depalma, 1949.

MEDAUAR, Odete. O direito administrativo em evolução. 3. ed. Brasília: Gazeta Jurídica, 2017.

MODESTO, Paulo. Nepotismo em cargos político-administrativos. Revista Brasileira de

Direito Público. Ano 11, n. 41, abr./jun. 2013, Belo Horizonte: Ed. Fórum.

ROCHA, Cármen Lucia Antunes. Princípios Constitucionais da Administração Pública. Belo Horizonte: Del Rey, 1994.

SILVA, Virgílio Afonso da. A constitucionalização do direito: os direitos fundamentais nas relações entre particulares. São Paulo: Malheiros, 2005.

STIRN, Bernard. Les sources constitutionnelles du Droit Administratif: introduction au Droit

Public. 5. ed. Paris: LGDJ, 2006.

VEDEL, Georges. Les bases constitutionnelles du droit administratif: études et documents du Conseil d'État. Paris: EDCE, 1954. 